\title{
Motivation in Second Language Learning: A Historical Overview and Its Relevance in a Public High School in Pasto, Colombia
}

\author{
Motivación en el aprendizaje de una lengua extranjera: \\ un resumen histórico y su importancia en una institución \\ educativa pública en Pasto, Colombia ${ }^{*}$
}

\author{
Mario Guerrero \\ mguerrero3@fordham.edu \\ University of Leicester, Leicester, United Kingdom
}

Motivation has a significant role in the process of language learning. It is important to understand its theoretical evolution in this field to be able to consider its relevance in the learning and teaching of a foreign language. Motivation is a term that is commonly used among language teachers and language learners but perhaps many are not aware of the different theories related to this topic and their teaching implications. This essay is an attempt to understand motivation over the past forty years in the different theories associated with language acquisition. Finally, there is a personal comment on motivation and its relevance at a public high school in Pasto, Colombia.

Key words: motivation, second language learning, second language teaching.

La motivación juega un papel importante en el proceso de aprendizaje de una lengua. Es primordial entender en detalle la evolución teórica de la motivación en el campo de la enseñanza. La motivación es un término que frecuentemente lo utilizan profesores y estudiantes de idiomas pero no obstante parecen desconocer las implicaciones teóricas de este término en la enseñanza. Este artículo pretende describir la evolución de las teorías de la motivación a lo largo de los últimos cuarenta años en el campo de la ense-

* Received: August 22, 2014. Accepted: December 12, 2014.

How to cite this article (APA $6^{\text {th }}$ ed.):

Guerrero, M. (2015). Motivation in second language learning: A historical overview and its relevance in a public high school in Pasto, Colombia. HOW, 22(1), 95-106.

This article is licensed under a Creative Commons Attribution-NonCommercial-NoDerivatives 4.0 International License. License Deed can be consulted at http://creativecommons.org/licenses/by-nc-nd/4.0/ . 
ñanza de idiomas. Por último, se hace una reflexión sobre la motivación en estudiantes de idiomas en un colegio público en la ciudad de Pasto, Colombia.

Palabras clave: aprendizaje de una segunda lengua, enseñanza de una segunda lengua, motivación.

\section{Introduction}

It is common to hear that the success or failure of a language learner to master a second language (L2) depends on their motivation. Motivation is usually associated with commitment, enthusiasm, and persistence to achieve goals. The Oxford Online Dictionary defines motivation as the "desire or willingness to do something" (Motivation, 2014). The Psychology Dictionary Online defines motivation as: (1) the driving force setting a direction to the behavior of humans and animals at a conscious and unconscious level, and (2) the willingness of a person to achieve a goal at a physical or mental level (Motivation, n.d.). Therefore, teachers play a relevant role in this process as they should know how to motivate students. Unfortunately, it is said that keeping students motivated is the second most complicated challenge for teachers (Hadfield \& Dörnyei, 2013). As a language teacher, you sometimes work with students who have very defined goals and a disposition to learn. Sometimes this translates into a more productive and satisfying teaching and learning experience. Nonetheless, other students seem to take a language class because they "have to" and their learning process might result in a slower or less enjoyable process.

The purpose of this essay is to describe and discuss theoretical L2 motivation principles in the field of second language learning over the past 40 years by reporting the key findings of relevant and recent research studies on motivation. Furthermore, a discussion on the relevance of L2 motivation to a pedagogical context in a high school in Colombia will be presented.

\section{L2 Motivation: Historical Evolution}

According to Dörnyei (as cited in Dörnyei \& Ushioda, 2011) there are three different stages in the history of motivation in foreign language teaching and learning. These phases are: (1) The social psychological period, (2) the cognitive-situated period, and (3) the process-oriented period.

\section{The Social Psychological Period (1959-1990)}

This period has been associated with the work of Robert Gardner in a bilingual context in Canada. According to Gardner (2010), motivation is a complex construct that does not have a simple definition, however, he states that a motivated individual is someone who sets a goal and perseveres to achieve it. Motivation is also the result of an interaction with the L2 culture 
Motivation in Second Language Learning: A Historical Overview and Its Relevance in a Public High School in Pasto, Colombia

and the target language. Therefore, considering Gardner's theory, social context and attitudes towards the L2 and L2 communities are the foundation to understand language learners' motivation. Fishbein and Ajzen (as cited in O'Rourke, 2011) define attitudes as the positive or negative response of an individual regarding a specific object. In terms of language learning, the authors mention that the "object" is evidently the target language.

Gardner and Lambert's (1972) theory of motivation draws an important relationship between motivation and orientation or "goal". Consequently, the authors proposed two terms that are commonly used in the field of motivation: Integrative orientation refers to the positive disposition of an individual to learn a language, its culture, and its community. Integrative motivated learners might have a significant and strong reason to learn the $\mathrm{L} 2$. On the other hand, instrumental orientation refers to the practical reasons of an individual to learn a language. Some people might be motivated to learn a second language as a required part of their studies, or to get a higher salary. Additionally, Gardner (1985) proposed integrative motive, which means the positive attitudes of an individual towards the L2 community.

It is important to mention that during this period there were other theories about motivation after Gardner and Lambert. Clément et al. (as cited in Kiil Molberg, 2010) developed the concept of linguistic self-confidence. This theory states that being part of a multilingual community may serve as a motivational aspect for any individual who may come in contact with the L2 community. In addition, Schumann (1986) proposed the acculturation theory. Acculturation is the integration of the learner into the L2 community. However, the simple intercultural contact with the L2 community is only the first step in this learning process. Being part of this environment allows the learner to interact with L2 speakers and provides the learner with the necessary input for the learning to take place.

In this period, Gardner proposed most of the theories in L2 motivation. Despite the criticism by other researchers in this field, Gardner's theories have evidently served as the foundation and starting point to inspire other researchers in order to better understand motivation in the L2 field and in other fields. It is worth noting that Gardner's bilingual context in Canada inspired his research and findings. The focus on the attitudes of the individual towards both the L2 and the L2 community is probably not transferrable or applicable to other contexts that are monolingual. Hence, it would have been important to consider other aspects of society in communities where there might be more limitations in terms of the interaction with other L2 communities. This might be the case in Colombia where Spanish is predominantly the language used to communicate and the opportunities for its nationals to leave Colombia can generally be a challenging task due to visa and immigration restrictions. Finally, it would be interesting to consider the attitudes of the L2 community towards the English-speaking foreigners in order to be able to consider to what extent Colombian citizens might be interested in using English as the language with which to 
communicate. Some other issues might impact the motivation of learners in a specific context. For example, based on personal experience, illegal Latino immigrants in the US are not often welcome to fully participate in the American society. Many laws restrict immigrants as regards social immersion in this L2 community. Therefore, the attitudes from the L2 community should also be relevant in this theory.

\section{The Cognitive-Situated Period (1990's)}

While the social psychological period had its focus on the importance of attitudes and feelings of language learners towards the L2 communities and the L2, the cognitive period intended to bring the focus of the investigation back to the psychological field emphasizing mainly cognition (or mental processes.) The learning contexts and the needs of the students and teachers in the classroom were considered more significant than the community and the social context. This did not mean that the social and psychological findings were disregarded — in fact, the idea was to broaden the previous theories but with consideration for other cognitive perspectives.

The first researchers to criticize the theories of the social psychological period were Crookes and Schmidt (as cited in MacIntyre, 2002). They stated that there were aspects that needed to be considered and other aspects that had not been given the importance they deserved in L2 motivation. Crookes and Schmidt (as cited in MacIntyre, 2002) reviewed three different theories related to motivation. They were: (1) speech accommodation theory (Giles \& Byrnes), (2) acculturation theory (Schumann), and (3) monitor model (Krashen). Finally, these two authors used Keller's "determinants of motivation" — interest, relevance, expectancy, and outcomes - to understand motivation in more specific contexts such as the classroom and the syllabus (MacIntyre, 2002).

In addition, Dörnyei (1994) proposed motivation on three different levels, which also contributed to this period:

a. Language level: it considers the language and the community as well as the instrumental and integrative motivations proposed by Gardner.

b. Learner level: involves the learner's personal traits and cognitive processes.

c. Learning situation level: it focuses on three specific learning levels in the classroom (teacher, course, group).

During this same cognitive-centered period of time, there was also an important interest in researching task-based instruction in the L2 field. Dörnyei (2002) defines an instructional task as a "discreet unit of situated learning behaviors" (p. 139) concerning the goal and outcomes of the same task. This made the analysis of motivation in this field less challenging due to the fact that the motivational theory proposed by Dörnyei involves previous aspects 
Motivation in Second Language Learning: A Historical Overview and Its Relevance in a Public High School in Pasto, Colombia

proposed by Gardner, but most importantly because this theory takes into consideration specific aspects inside the pedagogical process (Dörnyei \& Ushioda, 2011). Finally, Tremblay et al. (as cited in Dörnyei, 2002) proposed trait and state motivation. Trait refers to a particular person's motivation whereas state motivation refers to a more specific or temporary learner motivation.

In this period the transition from a general to a more specific perspective in the understanding of $\mathrm{L} 2$ motivation becomes more evident. This does not disregard the previous theories in the social and psychological period-but it serves as the foundation to explore other areas where L2 motivation had not been studied. It is also interesting to see how Gardner's instrumental and integrative terms have served as a basis for other terms that included more aspects of the learner as is the case in Dörnyei's (1994) three level theory and the trait/state motivation terms proposed by Tremblay et al. Furthermore, during this period there was a greater interest in learners and their learning experiences as opposed to the focus on the attitudes towards the L 2 in the previous period. This focus possibly proved to be fundamental for other researchers in order to understand that L2 motivation was not only influenced by social and psychological aspects, but it was also influenced by more specific aspects inside the classroom such as the curriculum, the syllabus, the learners' needs, and the role of the teacher. Finally, the use of tasks as tools to measure L2 motivation, proposed by Dörnyei (1994), sets an easier way to break down the understanding of motivation in the learning process. With this in mind, motivational research can be analyzed into smaller and probably more tangible aspects in the learning process.

\section{The Process-Oriented Period}

This period has three important perspectives on L2 motivation:

a. The first one by Williams and Burden (as cited in Dörnyei \& Ushioda, 2011) proposed two terms: (1) Motivation for engagement: wishes, intentions, decisions, and (2) Motivation during engagement: feelings, behavior during the learning process.

b. Ushioda (as cited in Dörnyei \& Ushioda, 2011) focused on the learner's temporary motivation. This theory emphasized motivation during the learners' experiences (positive L2 experiences in the past, relevant experiences to their learning process) and the motivation directed towards the learner's future goals (personal goals, priorities, incentives).

c. Dörnyei and Otto's theories (as cited in Dörnyei \& Ushioda, 2011) were the most complete ones that were proposed during this period. Their approach considered two stages: (1) Action stage: goals translate into intentions and achievements, and (2) Motivational stage: motivational forces pre-actional (e.g., setting goals), 
actional (e.g., registering for a language class), post-actional (e.g., external feedback or personal beliefs).

This period clearly shows a more special interest in language learners and their specific circumstances. Williams and Burden (1997), for instance, considered the learning process before and during the classroom experience. Dörnyei and Otto (as cited in Dörnyei \& Ushioda, 2011) proposed the learner's motivational stages suggesting that motivation needed to be explored from other perspectives at the learner's personal level. Consequently, this period raises awareness on learners and their specific learning context in L2 motivational research. The latter will result in the beginning of the new and most recent phase of L2 motivational research (Dörnyei \& Ushioda, 2011).

\section{Recent L2 Motivational Theories}

The socio-dynamic period is known to be the most recent phase in the research of L2 motivation. As its name suggests, the focus on constant change and the learner's interaction play a fundamental role in this new phase. Furthermore, the use of English as an international language raises concerns in terms of motivation. In other words, there seems to be a greater interest from language policy-makers in the learning of English as an essential academic objective for the new generations (Dörnyei \& Ushioda, 2011). This new period has three approaches:

a. Person-in-context: clear differences between the linear and dynamic perspectives are considered in this approach. A learner is not seen as cause-effect; instead he or she is seen as a dynamic unique individual. This means that learners need to be considered as "real persons." The latter means that there should not only be a focus on the learning process in the classroom, but there should also be a focus on the learners' social and personal aspects (Dörnyei \& Ushioda, 2009).

b. The L2 motivational self: proposed by Dörnyei (as cited in Dörnyei \& Ushioda, 2011); it is an approach that considers the learner on three different levels: (1) ideal L2 self (when the learner wants to speak the L2), (2) ought-to L2 self (the characteristics that a learner should have in order to avoid negative learning results), and (3) L2 learning experience "related to the environment and learning conditions” (Dörnyei \& Ushioda, 2011, p. 86).

c. Complex dynamic system: this approach has been associated with the movement of a double pendulum. The reason is because two or more variables are taken into consideration. These variables in L2 motivation are interlinked and constantly changing over time making it complex and unpredictable to foresee the results of an individual's behavior. Dörnyei (as cited in Dörnyei \& Ushioda, 2011) proposed the learner's individual differences (ID) might always be a challenge to understand and 
especially to generalize about as each individual has a combination of personal, emotional, and cognitive characteristics. These ID's are defined as attributes that make each person unique. Finally, Dörnyei (Dörnyei \& Ushioda, 2009, 2011) thinks that based on human behavior, it is possible to contemplate motivation, cognition, and affect as three broad different perspectives in the understanding of L2 motivation. This proposal is in sync with the socio-dynamic approach as none of these three perspectives can be seen separately or static.

In this current period, there has been a major shift in terms of the focus of the research in L2 motivation compared to the one in previous periods. First of all, the approach is not linear or predictable as it was before. Learners are unique and possess different personal, social, familiar, and professional characteristics that might influence their motivation towards the L2 learning process. Also, there is a realization that individuals and L2 motivation involve a dynamic process rather than the static conception previously considered. This means that learners are in constant change, which also involves a constant change in their feelings and interests. Our globalized societies tend to offer individuals an opportunity to have more interaction with other language communities and access to learning resources. These opportunities might have an influence on the motivation towards the L2. The need to understand that L2 motivation is the result of more than two variables also plays a vital role in this period because it is clear that results are not predictable. Individuals have very distinct personal and emotional traits that cannot easily be measured with one approach. Some of the downfalls of the new approaches in this period seem to suggest that these studies are still too theoretical and the lack of evidence implies that no assumptions or generalizations can be made (King, 2014).

\section{L2 Motivation in a Specific Pedagogical Context}

\section{Educational Context}

Colombia is a developing country in South America. Spanish is the official language. I have been part of this institution (high school) as both a student and teacher trainee and have developed educational projects after I graduated. These endeavors involved the development of community-based projects between the department of English in this high school and the local public university in the same city. Pasto is a very small city located in the south of Colombia. Its economy is based on agriculture and due to the war conflict, tourism in this area has rarely attracted people from other countries in the past 40 years. The opportunities for people in this region to speak to others in a different language do not seem to be relevant. Nonetheless, it is important to mention that social media and the effort of the Colombian 
government to provide Colombian citizens with mobility opportunities seems to have broadened the travel and work abroad alternatives.

The institution. Normal High School is a public institution that was founded in 1911 with the purpose of preparing high school students to become future primary and high school teachers. The long trajectory of this institution and the support of the local and national governments have allowed this high school to become one of the most prestigious institutions. In addition, the current administration has not only invested in new technological equipment for all of the subjects but has also formed new partnerships with different universities and other educational institutions in order to provide faculty members and students with better learning and teaching opportunities. One of the new technology rooms in this institution includes cutting edge laptops, computers with access to the Internet with specialized dictionaries and subscriptions to English online laboratories. This is evidently a major opportunity for English language teachers and students because it serves as a tool to improve their proficiency skills. Unfortunately, the institution has only one English laboratory and the number of students is greater. This prevents students from having access to this room at any time.

The students. Normal High School had 3,772 registered students in 2010 (Burgos, 2011). Most of the students are from Pasto and the city's surrounding villages. This is a public high school and, even though there are no official data sources, most of the students come from low-income families. The ages of the students are from 3 to 4 years old in kindergarten, 5 to 11 years old in primary school and 12-18 years old in high school. Students are required to pay a small registration and matriculation fee every year.

Faculty and English language curriculum. Normal High School's curriculum has nine major subject areas. English language is part of the Humanities, Spanish Language and Foreign Language Department (Escuela Normal de Pasto, 2014). While it says foreign languages, the only foreign language offered is English. Normal High School students are not required to take English or any foreign language classes during their elementary studies. During the last six years in high school, students take compulsory English classes. English instruction is limited to two hours per week and classes have an average of 40 students in them. Students get prepared to take a national standardized test in all subjects including English. The test requires students to be able to read basic passages and to understand intermediate grammar concepts of the English language. No listening or speaking skills are tested. In terms of English language teachers, there are only four full time instructors. All of them are native Spanish speakers from Colombia. Their ages are 35 to 50 years old. In my role as a university lecturer, I was able to observe some English classes. Teachers deliver their classes mostly in Spanish and rely mostly on grammar-translation. Students are not required to use an English textbook due to the costs of the texts. The teachers bring into the class 
photocopies and other material relevant to the content of the lesson. I was also able to interact with some of the teachers in English and some of them were not able to maintain a basic conversation in English. Some of them have had the opportunity to visit the United States for holidays and the others have never been to an English speaking country. The teachers hold a bachelors degree in Modern Languages from the local university and some of them hold a "specialization degree" in English language teaching pedagogy. Specializations are degrees offered in Colombian universities after a bachelor's degree and before a master's degree.

\section{Motivation and Its Relevance at Normal High School}

After describing the theories on L2 motivation, let us consider their relevance to the aforementioned teaching context. I will consider the learning process of Normal High School students in three different contexts:

a. Social context. the theories of the social and psychological period suggest that learners' motivation is in sync with their attitudes towards the L2 and the L2 community. For Normal High School students, the interaction with the L2 is generally limited to the two hours a week of English instruction in their schools. As many of these students come from low-income backgrounds, the access to a computer and the Internet at home can be challenging. Public television is always in Spanish, which means that access to other L2 resources is very restricted. The opportunity for Normal High School students to travel abroad is also difficult. Since Colombia is considered a dangerous country, all English-speaking countries require Colombian nationals to apply for a tourist visa to visit their countries. Visa requirements are overwhelming and usually only granted to people with higher salaries. Nevertheless, English as an international language has raised awareness in companies and employers to demand a higher English proficiency level in Colombia. This might serve as an instrumental motivation for Normal High School students. Ushioda's (as cited in Dörnyei \& Ushioda, 2011) theory is also relevant as it pays attention to the future goals of each learner. Unfortunately, the foundations of Gardner's theories in the social period were based on a bilingual context. Many of these theories might not be relevant to a social context in Pasto for the reasons described before.

b. Language policy and teaching context. At a classroom level, instruction comes from teachers who, in general, have not had the opportunity to live, work or study in the L2 community. Some theories are relevant in this regard. Dörnyei's (1994) learning situation level considers the specific classroom and learning conditions. Additionally, William and Burden's (as cited in Dörnyei \& Ushioda, 2011) theory 
on the learner's previous and current classroom conditions are important in Normal High School students as future intentions and current classroom instruction are considered. Finally, it would be recommended to ascertain whether the teachers' methodology and their professional experience also influence learners' motivation. Few native English speakers have visited Pasto. The very few English language academies that exist tend to hire native English speakers who do not have the professional and educational background to teach English. It seems, therefore, that the only requirement needed to become a teacher is to be a native speaker. Based on personal experience, I registered for an Italian class taught by an Italian teacher who had never taught languages before. I lost interest in the class after two weeks and never attended this class again. While this was just a personal experience, there is a need to consider other students' experiences in order to get a better understanding of this personal experience.

c. Personal context. Despite the social context, the positive or negative L2 instruction, and the ambitious goals of the Colombian government, each Normal High School student is unique. There is no evidence these students have not learned English, or that they have never achieved higher proficiency language levels in the L2. I say this as a Normal High School alumnus and Colombian citizen who has achieved a higher proficiency in English as an L2. Dörnyei's (as cited in Dörnyei \& Ushioda, 2011) individual differences theory helps better understand this situation and supports the importance of the academic potential of each student. The person-in-context approach by Ushioda (2009) is useful also as it demonstrates that each learner should be seen as a "real person" with different characteristics. While the conditions might be the same for every Normal High School student, some might explore other strategies to improve their L2 knowledge.

\section{Conclusions}

L2 motivation has gone through different stages over the past 40 years. Gardner's theories served as a starting point to understand L2 motivation. Since then, the various motivation periods have gone through a process of evolution in which relevant theories were reformulated to specific learning contexts while some other approaches were criticized. The most recent period has interestingly brought our attention to the complexity of L2 motivation. This suggests that results cannot be predicted and more than two variables are involved in the learning process. Therefore, it continues to be difficult to agree on one single definition of L2 motivation. There are too many aspects and personal learners' traits to consider in the process of understanding their motivation towards second language learning. Finally, it can be claimed that many of the L2 motivational theories might not be applicable to 
Motivation in Second Language Learning: A Historical Overview and Its Relevance in a Public High School in Pasto, Colombia

every context. There are social, political, financial, and personal aspects that need to be considered.

\section{References}

Burgos, D. C. (2011, January 30). Educación de Pasto: entre deserción y hacinamiento [Education in Pasto: Between dropping out and overcrowding]. Diario del Sur. Retrieved from http://www.mineducacion.gov.co/observatorio/1722/article-262918.html.

Dörnyei, Z. (1994). Motivation and motivating in the foreign language classroom. The Modern Language Journal, 78(3), 273-284. http://dx.doi.org/10.1111/j.1540-4781.1994.tb02042.x.

Dörnyei, Z. (2002). The motivational basis of language learning tasks. In P. Robinson (Ed.), Individual differences and instructed language learning (pp. 137-158). Philadelphia, PA: John Benjamins. http://dx.doi.org/10.1075/lllt.2.10dor.

Dörnyei, Z., \& Ushioda, E. (Eds.). (2009). Motivation, language identity, and the L2 self. Bristol, UK: Multilingual Matters.

Dörnyei, Z., \& Ushioda, E. (2011). Teaching and researching motivation. Harlow, UK: Pearson Education.

Escuela Normal de Pasto. (2014). Educación Básica Secundaria [High-School Education]. Retrieved from http://www.escuelanormalpasto.edu.co/index.php?option=com_content\&view= article\&id $=38 \&$ Itemid $=38$.

Gardner, R. C. (1985). Social psychology and second language learning: The roles of attitudes and motivation. Baltimore, MD: Edward Arnold Publishers.

Gardner, R. C. (2010). Motivation and second language acquisition: The socio-educational model. New York, NY: Peter Lang Publishing.

Gardner, R. C., \& Lambert, W. E. (1972). Attitudes and motivation in second-language learning. Boston, MA: Newbury House Publisher.

Hadfield, J., \& Dörnyei, Z. (2013). Motivating learning: Research and resources in language teaching. Harlow, UK: Pearson.

Kiil Molberg, H. K. (2010). The consequence of motivation and linguistic self-confidence in relation to pupils' oral interaction. University of Tromsø, Norway. http://munin.uit.no/bitstream/handle/10037/ $2951 /$ thesis.pdf? sequence $=1$.

King, J. (2014). Second language learning. B6: Motivation [PowerPoint Presentation]. University of Leicester, United Kingdom.

MacIntyre, P. D. (2002). Motivation, anxiety, and emotion in second language acquisition. In P. Robinson (Ed.), Individual differences and instructed language learning (pp. 45-68). Philadelphia, PA: John Benjamins. http://dx.doi.org/10.1075/lllt.2.05mac.

Motivation. (n.d.). In Psychology Dictionary Online. Retrieved from http://psychologydictionary.org/ letter/m/page $/ 97 /$.

Motivation. (2014). In Oxford Online Dictionary. Retrieved from http:// www.oxforddictionaries.com/definition/english/motivation?q=motivation. 
O'Rourke, B. (2011). Galician and Irish in the European context: Attitudes towards weak and strong minority languages. Bristol, UK: Palgrave Macmillan.

Schumann, J. H. (1986). Research on the acculturation model for second language acquisition. Journal of Multicultural and Multilingual Development, 7(5), 379-392. http://dx.doi.org/ 10.1080/01434632.1986.9994254.

Ushioda, E. (2009). A person-in-context relational view of emergent motivation, self, and identity. In Z. Dörnyei \& E. Ushioda (Eds.), Motivation, language identity, and the L2 self (pp. 215-228). Bristol, UK: Multilingual Matters.

\section{The Author}

Mario Guerrero holds a Masters in Applied Linguistics and TESOL from the University of Leicester (UK) and a Masters in Educational Leadership from Fordham University (USA). He has taught English as a Second Language and Spanish in British and American Universities as well as English as a Foreign Language in a Colombian university. His research interests are related to language and gender, male written and spoken discourse analysis. 